\title{
КАДИОНИЦА СА ЛОКАЛИТЕТА ПЕРЛЕК-ХУМКА КОД БЕЧЕЈА
}

\author{
Рашко Рамадански \\ Градски музеј Бечеј \\ Александар Ристић \\ Народна библиотека „Др Милован Спасић” Рековац \\ Филозофски факултет, Универзитет у Београду \\ e-mail: r.ramadanski@gmail.com $\mid$ Прегледни рад \\ Примљено: 8. 5. 2020. УДК: 904:726"05/06"(497.11) \\ Прихваћено: 31. 7. 2020. 069.51:904”05/06”(497.11)
}

\begin{abstract}
Апстракт: Кадионица са локалитета Перлек - Хумка код Бечеја у Бачкој, иако је реч о случајном налазу, представља вишеструко значајно откриће. Кадиониче саме по себи нису честе а примерак из Перлека, ако се узму у обзир стилске особености, представља за појмове данашње Србије и региона јединствен налаз. Овај примерак се условно може датовати у 6. или прву половину 7. века, те је према томе реч о рановизанијском предмету. Кадионицама није једноставно одредити место израде. Према смерницама које нам допуштају неке од расположивих паралела из југоисточне Европе, Мале Азије и ирноморског приобаља, радионииу бисмо могли потражсити на простору источног Средоземьа. С обзиром на то да није документован изворни археолошки контекст налаза, може се само претпоставити порекло ове кадионище, притом на територији која није била у саставу Ромејског ијарства. Једна од вероватнијих могућности јесте да је донесена као плен са неког од аварских или словенских похода у префектуру Илирик. Налаз кадионице са локалитета Перлек-Хумка представља један од најранијих примера хришћанске материјалне културе у Бачкој.
\end{abstract}

Кључне речи: Перлек, Бечеј, Бачка, рана Византија, кадионица, богослужбени предмет

Током радова на позајмишту земље у атару Перлек и у подножју истоимене хумке северно од Бечеја, приликом изградње успона и нове деонице пута од Бечеја према Бачком Петровом Селу, приликом багеровања је 1970. године пронађена бронзана кадионица. ${ }^{1}$ Овај случајан налаз, иако нажалост изостаје документовани стратиграфски контекст, свакако завређује посебну пажњу, пре свега ако се узме у обзир географско место налаза, које значајно одступа од досадашњих просторних одредница ове врсте налаза. Осим тога,

\footnotetext{
${ }^{1}$ Инвентарна књига археолошке збирке Градског музеја Бечеј: ИБ (А) 883.

Гласник Српског археолошког друштва

Journal of Serbian Archaeological Society 


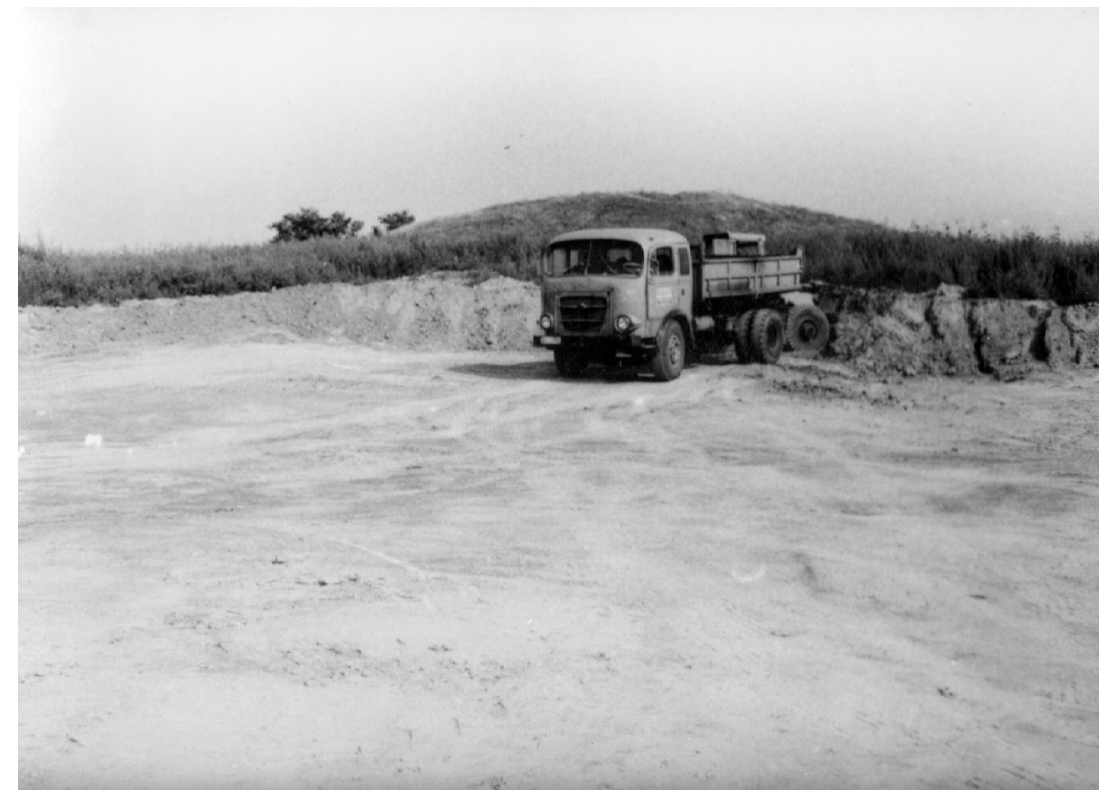

Сл. 1. Радови на позајмишту земље у подножју хумке у Перлеку (Фототека Археолошког одсека Градског музеја Бечеј)

Fig. 1. The works in the earth deposit at the base of the mound in Perlek

(Town Museum Bečej photo library)

стилске особености и репрезентативност, као и реткост ове врсте предмета, додатно одликују овај налаз. Кадионица је похрањена у Градском музеју Бечеј, налази се на Археолошком одсеку и заведена је у археолошкој збирци под ознаком ИБ (А)883. Узорно је очишћена и конзервирана, а најскорији захвати на предмету изведен је приликом припреме за изложбу поводом педесетогодишњице Музеја у Бечеју 2003, односно изложбе поводом издања Eдикm у Музеју Војводине у Новом Саду 2014. године. ${ }^{2}$ У литератури се срећу само општи подаци, без подробнијих запажања или интерпретације (Група аутора 2014, 77-79, кат. бр. 71). Ово је први пут да је налаз кадионице са локалитета Перлек-Хумка тема засебног рада и надамо се да ће се овом приликом скренути неопходна пажња на овај вредан и необичан налаз, уз његово што је могуће правилније датовање и интерпретирање.

Перлек је назив за атар северно од Бечеја у Бачкој и налази се на алувијалној равни реке Тисе. Перлек и Доњи рит простиру се дуж лесне греде, или старе обале на западу, све до јужне стране насеља Бачко Петрово Село, а од мртваје Медењаче и Великог рита на истоку, атар Перлек је одвојен тра-

\footnotetext{
${ }^{2}$ Видети: Микић-Антонић 2003; Група аутора 2014.
} 
сом данашњег пута. На северном излазу из Бечеја налазиле су се две хумке, од којих је до данас у целости опстала само она већа, епонимна хумка, док је мања, јужна хумка у највећој мери разорена приликом рада копача и механизације који су у прошлости одатле црпили земљану сировину (сл. 1). У профилу мање хумке, или њеној непосредној околини, пронађена је кадионица а ови профили су и данас доступни (сл. 2). Хумка Перлек се среће на картама почев од Другог војног премера Хабзбуршког царства, где je уписана пре 1869. године под називом (немачки) Perleg Hügel. ${ }^{3}$ Најранији познати помен топонима Перлек (латински Perlek), као насеља са царинарницом у надлежности Бечеја, потиче из 1440. године, а као посед српског деспота Ђурђа Бранковића (1427-1456) помиње се 1441. године (Szekeres 1983, 43-44). У том светлу, на археолошком локалитету недалеко од хумке констато-
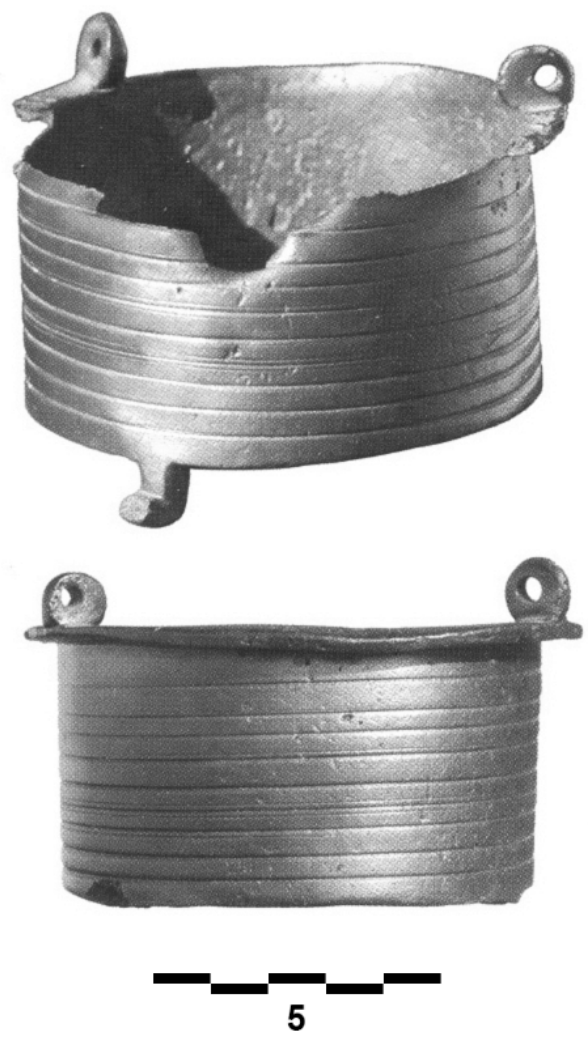

Сл. 2. Кадионица из Перлека код Бечеја (Према: Група аутора 2014, 79)

Fig. 2. The censer from Perlek near Bečej (According to: Група аутора 2014, 79) вано је и позносредњовековно насеље, док се о месту раносредњовековног насеља још увек само претпоставља (Станојев 1996, 42). Локалитет у целости називамо Перлек-Хумка.

Кадионица из Перлека начињена је од бакарне легуре, највероватниjе бронзе. ${ }^{4}$ Кадионица је цилиндрична, хоризонтално наглашеног тракастог обода, на којем су распоређене три вертикалне, овалне ушице. Реципијент је украшен са девет паралелно урезаних жлебова, од којих четири прате један или више тањих уреза, а цео предмет је почивао на три ноге у облику слова

\footnotetext{
${ }^{3}$ Die zweite militärische Aufnahme 1806-1869, ARCANUM Adatbázis Kft, Digitized Historical Maps - DVD издање, љубазношћу Историјског архива у Сенти.

${ }^{4}$ Упутно би било предузети испитивање како ове тако и других рановизантијских кадионица у Србији преко XRF спектрометрије, помоћу које бисмо много боље сагледали метални састав предмета те направили корак у правцу утврђивања места израде.
} 


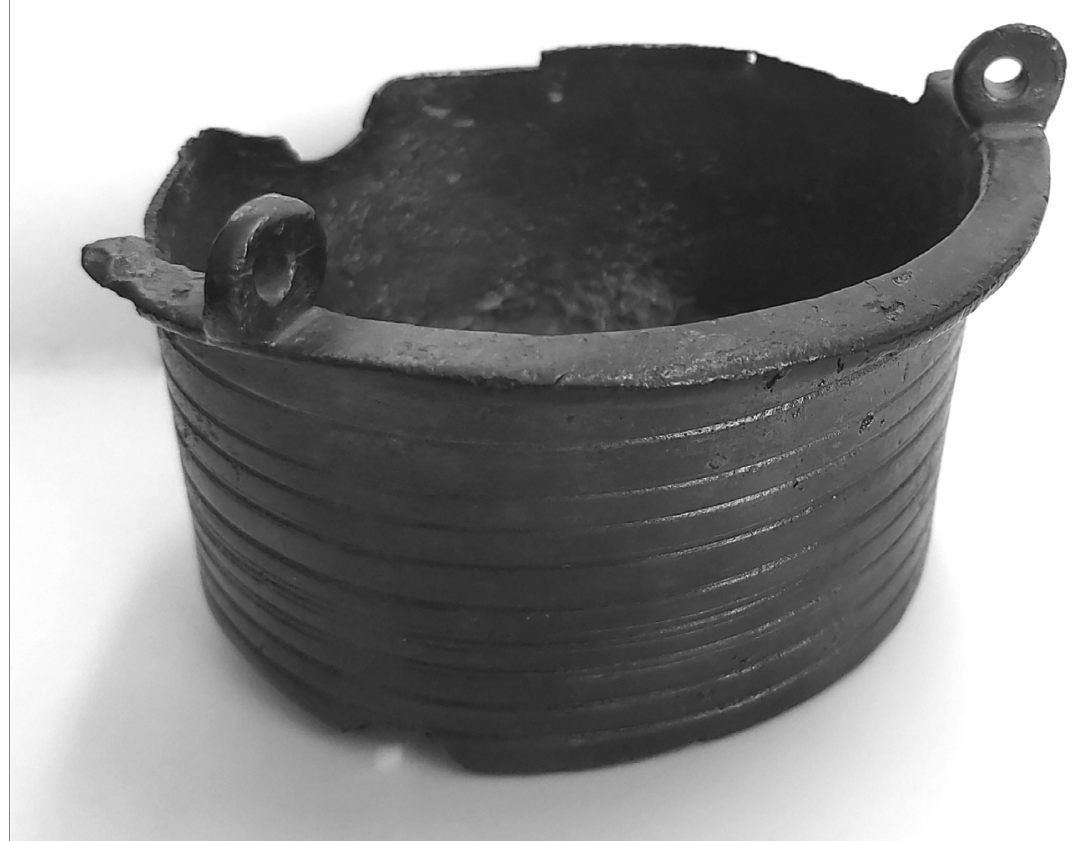

Сл. 3. Кадионица из Перлека код Бечеја (Фотографисао Рашко Рамадански)

Fig. 3. The censer from Perlek near Bečej (Photographed by Raško Ramadanski)

„Г”. Нажалост, кадионица је пронађена оштећена. Наиме, недостаје приближно половина обода са једном од ушица и делом реципијента. Недостају и две ноге, док је код преостале трећина одломљена. На једном месту на ободу примећују се и неравнине настале услед дејства штетне корозије, која је приликом чишћења и конзервације заустављена и неутралисана. Укупна висина кадионице, од ушице до ноге, износи 8 цм, док је сам реципијент висок 5,4 цм. Ширина обода варира од 0,8 до 0,9 цм. Пречник реципијента је 9,5 цм док је пречник обода 11 цм. Размаци између паралелних бразди су до 0,5 цм. Нога је висока 1,2 цм и истурена је 0,6 цм у односу на реципијент. Предмет је тежак 368 грама. Кадионица је сасвим сигурно ливена, вероватно применом технике „изгубљеног воска”, на шта нас упућује хомогеност целог предмета као и ситне пукотине на површини метала које настају приликом самог ливења. Затим, примећујемо трагове ручне дораде, углавном абразијом на местима где је било потребно уклонити трагове неправилности, или раскуцавањем на местима где је требало кориговати неки облик. Ушице на којима је кадионица висила очигледно су пробушене након ливења а трагови перфорације су састругани. Поменути паралелни украси на спољашњости реципијента кадионице израђени су стругом, на шта нас упу- 
ћују местимични зупчасти трагови у украсним браздама, који настају услед трења сечива струга приликом урезивања у метал док се предмет окреће у правцу супротном углу струга. Ово као и релативна симетрија украса и делимично понављање неких од уреза у плићем негативу упућује на примену некакве ручне (или ножне) центрифуге. Свакако, реч је о сложеној и постепеној техници израде предмета.

Богослужбени предмет под називом кадионииа (или кадндьннца, грч-

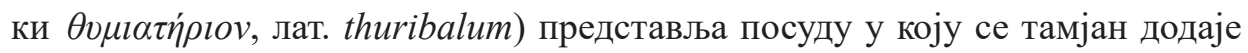
поврх жара, те се њоме кади ${ }^{5}$ на одређеним местима и у одређено време током богослужења (Мирковић 1918,120$)$. Према форми и начину употребе се могу поделити на висеће и ручне. Висеће кадионице, најчешће израђиване од бронзе, причвршћиване су за ланце и могу бити подељене на оне са поклопцем или без њега, уз додатак звончића или без њих. Постоје и једноставнији примерци са звончићима, само без ланаца, који се користе током одређених служби као нека врста цимбала које прати појање (Ивковић 1988, 103; Фундулис 2004, 36). Кадионицама се испољава поштовање икона и других реликвија, док се кађењем верника примају њихове молитве, а уједно и дели освећење кроз мирис тамјана (Мирковић 1918, 120; Фундулис $2004,36)$. Приликом чинодејствовања, свештеник се (на)клања и осењује крсним знаком оне који се каде и истовремено клањају. У храму се могу кадити олтар или цео храм, као и поједини делови сакралног простора или саме реликвије. Л. Мирковић сматра да су првобитне кадионице биле са дршком, док су у каснијем периоду добиле данашњи изглед (Мирковић 1918, $120,318-319)$, док Ј. Фундулис указује да је кадионица првобитно употребљавана приликом опела и помена, то јест у контексту поштовања мртвих (Фундулис 2004, 36). Византијски историчар цркве, Евагрије Схоластик, бележи податак да је персијски цар Хозроје II (590-628) поклонио цариград-

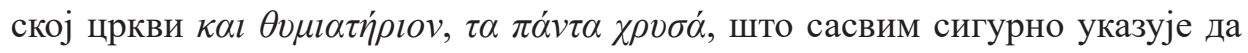
су кадионице већ биле у употреби у том периоду (Bidez и Parmentier 1898, 238; Мирковић 1918, 130). Цариградски патријарх Герман I (715-730) сматрао је да ови богослужбени предмети имају и симболичко значење, према коме Et statim thuribulum subindicat humanitatem Christi, ignis divinitatem et fragrans fumus indicat illum bonum odorem sancti Spiritus praecedentem (кадионица значи човечанство Христа, жеравица божанство, а дим што се диже из кадионище означава добар мирис Св. Духа). ${ }^{6}$ Иако постоје извори,

\footnotetext{
5 „ка́дити, 3. цркв. при верском обреду махати кадионицом из које се шири дим и мирис запаљеног тамјана", према: Стевановић et al. 1967, 623.

${ }^{6}$ Према: Migne 1865, 399.
} 
попут Liber Pontificalis, који указују да је Константин I даровао златне кадионице Латеранској базилици, не може се прихватити њихова еклезијална употреба пре самог краја 4. века (Augusti 1831, 72). С друге стране, поједини аутори описују и случајеве профане употребе кадионица и током 6-7. века (Brokalakis 2005, 44). Све до 8. века, кадионице су биле кубичног, полигоналног или цилиндричног облика, са нешто ређом употребом поклопца. Најчешћи тип кадионица тог времена биле су оне облика путира на ниској стопи, и са рељефним представама јеванђеља. Такав тип кадионица заступљен је са преко 50 познатих примерака и претпоставља се да су коришћене и након иконоклазма (Bouras и Kazhdan 1991, 397). Позније кадионице, из времена одмаклог и позног средњег века, било да је реч о источноправославном или римокатоличком обреду, зацело су другачије од својих претеча. ${ }^{7}$

Археолошки материјал хришћанског карактера са територије централног Балкана, у мери у којој је до сада откривен и проучен, указује на центре и области одакле се хришћанство постепено ширило на простор северног Илирика. Наиме, хришћанство је у овој области већ у 6. веку било веома распрострањено, чему сведоче бројне документоване сеоске цркве, које се неретко налазе и на мање приступачним местима (Милинковић 2015, 33). Покретни материјал сакралног карактера израђиван је у радионицама широм Царства, а поједини примерци су и трговачким везама допремани на простор централног Балкана, те њихова бројност указује на већи степен христијанизације на овом простору у распону од 4. до 7. века (Ilić 2006, 47-48). Хронолошки и географски најближа паралела кадионици са локалитета Перлек-Хумка код Бечеја откривена је 1977. године у касноантичкој вили близу рудника Бела вода у Пернику (Бугарска). Овај објекат, приближних димензија 40 х 40 м, датован је у време од краја 3. до почетка 5. века (Любенова 1995, 6). Приликом ових истраживања откривен је предмет готово идентичан нашем примерку, цилиндричног облика, са плитко урезаним хоризонталним круговима и са хоризонтално профилисаним ободом. На врху предмета се налазе алке за качење, а на дну су постављена три стопала у облику слова „Г”. Висина кадионице износи 6 цм, док њен пречник износи 7,3 цм. Троструким ланцем дужине 24 цм предмет је био окачен за алке. Међутим, овај налаз је неадекватно интерпретиран као светиљка, односно кандило. Поред нетачне типолошке детерминације, предмет је и хронолошки проблематично датован у време 4. века (Любенова 1995, 9, Обр. 3, Обр. 10/г).

\footnotetext{
${ }^{7}$ Видети: Zdravković и Simić 1956, 247-248; Брмболић 1984, 21; Ивковић 1988, Сл. 1, 4; Бајаловић - Хаџи-Пешић 1992, 217-218; Lovag 1999, 81-84, 220-226; Minić и Vukadin 2007, 148-149; Миловановић 2008, 310-327.
} 


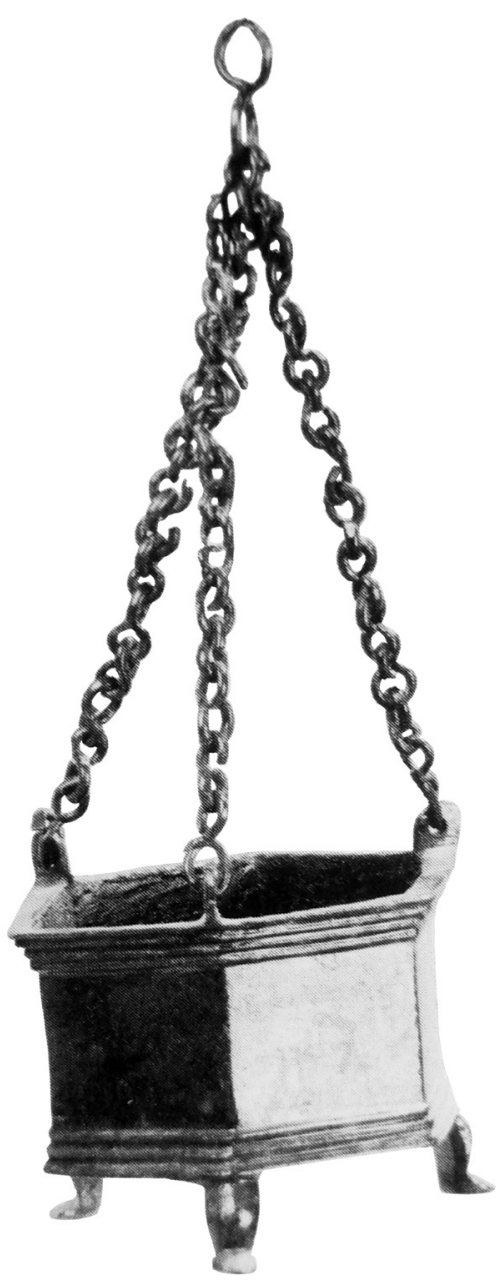

Сл. 4. Шестоугаона кадионица из Гамзиграда (Према: Јанковић 1983, 138)

Fig. 4. The hexagonal censer from Gamzigrad (According to: Јанковић 1983, 138)
Још један близак налаз откривен је у слоју С-Е унутар куле старијег утврђења Гамзиграда, где је пронађена остава црквених предмета од бронзе. У питању је скуп налаза састављен од полијелеја, кадионице, канделабра и различитих окова. Бронзана шестоугаона кадионица има профилисану основу и обод, три ножице и три ушице. Предмет је био окачен на три ланца, спојена при врху кариком у облику осмице, али код овог примерка недостају крст и рукохват. На једној од страна кадионице је накнадно затворен правоугаони отвор (сл. 4). Висина предмета је 7,5 цм, а читава ова група налаза сведочи о распрострањености хришћанства на подручју око Гамзиграда у 6. веку. О томе говоре и остали предмети религијског карактера, као и остаци сакралне архитектуре (Јанковић 1983, 135-136, 138). Такав тип кадионица представља чест налаз на читавом простору Царства, што указује на уједначеност у њиховој производњи и упућује на постојање производних центара, највероватније у Египту, или на Криту (Brokalakis 2005, 48; Ilić 2006, 51). Неки од локалитета где су пронађене шестоуагоне кадионице јесу Сард у Малој Азији и Елефтерна на Криту (Brokalakis 2005, 44-45, Fig. 14-16). Постоје и луксузнији варијетети шестостране кадионице, од сребра са позлатом и рељефима са мотивима из Новог завета, попут кадионице из Несебра у данашњој Бугарској, која се датује у крај 6. или сам почетак 7. века (Frazer и Evans 1999, 37, кат. бр. 45). Други налаз кадионице на територији данашње Србије, иако нешто позније, откривен је у атару села Пепељевца код Куршумлије, уну- 


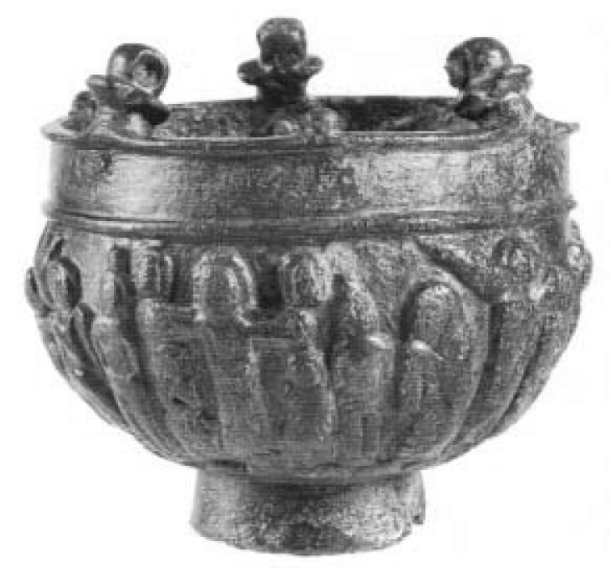

Сл. 5. Конична кадионица из Пепељевца код Куршумлије (Према: Ћоровић-Љубинковић 1950, 72)

Fig. 5. The conical censer from Pepeljevac near Kuršumlija (According to: Ћоровић-Љубинковић 1950, 72)

тар остатака Цркве Св. Недеље. У питању је висећа бронзана биконична кадионица на нози, или стопи, без поклопца, израђена ливењем, а на њој се налазе новозаветне рељефне представе. На ободу се налазе три кружне петље, којима је предмет био причвршћен за ланце (сл 5). Висина предмета је 8,5 цм, пречник отвора је 12 цм, пречник стопе је 4,8 цм а висина ноге 1,5 цм (Ћоровић-Љубинковић 1950, 70-72). Слични примерци, који углавном воде порекло из Египта, нађени су и у области Средоземља и неким деловима Европе, па је изнета претпоставка да радионичарске центре у којима су израђиване овакве кадионице, крајем 7. или почетком 8. века, треба тражити на простору данашњег Египта (Ilić 2006, 51; Илић 2008, 129-130; Шпехар $2017,186)$. Готово идентичан примерак са сценама из Христовог живота данас се налази у збирци Историјског музеја у Сочију (Khrushkova 2018, 61-63, Fig. 3-8). Поменули бисмо још и то да се веома слична кадионица из Музеја Института за уметност у Детроиту датује чак и до 10. века (Sandin 1993, 47, Figure 2). Осим раније наведених налаза који деле хронолошку или географску блискост са налазом из Перлека, типолошки можда најсличнија рановизантијска кадионица јесте цилиндрична кадионица са наглашеним ободом, натписом и три ноге и ушице, из колекције П. Анагносту из Атине (Touchais et al. 1998, 712-713, Fig. 7). Неки од предмета из исте збирке датуjy се у 6. век (Touchais et al. 1998, 712). Сматрамо да је смислено поменути и неке од познијих примерака кадионица које су сличне налазу са локалитета Перлек-Хумка. Ради се о две кадионице пронађене у оставама при- 
ликом археолошких истраживања на простору античког каструма Понтес (лат. Pontes) током 1981. и 1982. године. Остава II састојала се од бронзане кадионице, гвоздене узенгије, гвоздених српова и копче за појас, док се у оближњој Остави III налазила бронзана кадионица са копчама за корице књиге (Гарашанин и Васић 1987, 81). Кадионица из прве оставе је мања и плића, биконичног је облика и садржи три кружне петље кроз које су пролазили ланци за качење предмета. Други предмет има нешто дубљи конични лимени рецепијент са стопом, на чијем су ободу симетрично постављена три мања кружна отвора за провлачење ланаца, у горњем делу повезивана куком. Оставе су датоване у 9-10. век (Шпехар 2017, 189). Географски нешто даља, али хронолошки ближа паралела потиче из Старе Врлике у Далмацији. Тамо је откривена богато украшена сребрна кадионица, која је била причвршћена за три ланца и за коју се претпоставља да је настала средином 8. века (Vinski-Gasparini 1958, 93-103). Узмемо ли у обзир ликовне изворе, запажамо да је хронолошки најприближнији извор управо приказ кадионице на мозаику Базилике Сан Витале у Равени, задужбине византијског цара Јустинијана I (527-565), која је завршена 547. године. Лево од представе цара приказани су епископ и двојица ђакона, од којих један у десној руци држи висећу кадионицу (Andrescu-Treadgold и Treadgold 1997, 708; SalesCarbonell et al. 2017, Fig. 2). Изглед кадионице из овог ликовног извора упадљиво подсећа на тип кадионице из Перлека.

Ако узмемо у обзир интерпретације нама доступних паралела, склони смо да датујемо кадионицу из Перлека у другу половину 6. или половину 7. века, и да је сматрамо за пример рановизантијске материјалне културе, а да њено место израде потражимо у источном Средоземљу (Крит, Синај, Египат). Ради се о типу кадионице који до сада није био документован код нас, а чињеница да је пронађена на територији која није била у саставу Царства додатно наглашава њен значај. У делу Едикт наведено је да кадионица потиче са локалитета насеља или некрополе 8-9. века (Група аутора $2014,78)$. Међутим, о томе не постоје трагови у музејској документацији и по свој прилици је реч само о претпоставци. Познати локалитет средњовековног насеља налази се око 300 метара југозападно од хумке док се на ораници која дели два локалитета не запажају уломци керамике савремене кадионици, што у целини не оспорава да је и тај део потеза био настањен. У међувремену је установљено да је почетком седамдесетих година 20. века механизација, попут багера и камиона, кориштена на позајмишту земље које се налазило западно од данашњег пута, у подножју хумке. И заиста, на траговима мање хумке запажају се јасни показатељи експлоатације жуте зе- 
мље - леса. Са саме хумке, како велике тако и мале, не потичу други познати археолошки налази, али с обзиром на то да се ради о хумкама, односно трајним и препознатљивим одликама у рељефу, можемо претпоставити и да је кадионица део својеврсне оставе или одложеног (можда одбаченог) плена из неких од похода Авара или Словена у префектуру Илирик. Није незамисливо да су они понели између осталог и кадионицу као део опљачканог инвентара или ризнице неке цркве. С друге стране, не искључујемо могућност да се могло радити и о некаквом станишту или гробној целини, а ако се у будућности веродостојнијим испостави неко позније датовање саме кадионице, за шта такође постоје полазишта у датовању неких од паралела, налаз потенцијално може упућивати и на локацију раносредњовековне богомоље, у том случају веома ране за појмове Бачке. Независно од претпоставки о томе како је ова кадионица доспела у своје коначно исходиште, овај налаз представља један од најранијих примера хришћанске материјалне културе у Бачкој и као такав заслужује да буде познат научној и широј јавности, и да буде разматран у неким будућим радовима.

\section{БИБЛИОГРАФИЈА}

Andrescu-Treadgold, I. и Treadgold, W. 1997. Procopius and the Imperial Panels of S. Vitale, The Art Bulletin 79/4: 708-723.

Augusti, J. C. W. 1831. Denkwürdigkeiten aus der christlichen Archaeologie 12. Leipzig: in der Dykschen Buchhandlung.

Бајаловић-Хаши-Пешић, М. 1992. О налазима неких предмета у готичком стилу на територији Србије, Саопштења XXIV: 217-222.

Bidez, J. и Parmentier, L. (ур) 1898. The Ecclesiastical History of Evagrius with the Scholia. London: Methuen \& Co.

Bouras, L. и Kazhdan, A. 1991. Censer, у The Oxford Dictionary of Byzantium, yp. A. P. Kazhdan, 397. New York - Oxford: Oxford University Press.

Брмболић, М. 1984. Манастир Намасија. Параћин: СИЗ културе општине Параћин. Brokalakis, Y. 2005. Bronze Vessels from Late Roman and Early Byzantine Eleutherna on Crete, AnTard 13: 37-50.

Vinski-Gasparini, K. 1958. Ranosrednjovjekovna kadionica iz Stare Vrlike, Starohrvatska prosvjeta III/6: 93-103.

Гарашанин, М. и Васић, М. 1987. Castrum Pontes - Извештај о ископавањима у 1981. и 1982. години, у Ђердапске свеске IV, ур. В. Кондић, 71-116, Београд: Археолошки институт, Народни музеј, Одељење за археологију Филозофског факултета. Група аутора. 2014. Каталог, у Едикт, ур. А. Озер, 67-152. Нови Сад: Музеј Војводине. Zdravković, I. и Simić, M. 1956. Manje crkvene građevine і zgrade iz turskog doba na Novom Brdu i okolini, Glasnik muzeja Kosova i Metohije I: 247-248. 
Ивковић, 3. 1988. Кадионице и њихове ликовне представе у средњовековној Србији, у Рашка баштина 3, ур. С. Ђорђевић, 103-116. Краљево: Завод за заштиту споменика културе.

Ilić, O. 2006. Ranohrišćanski import na teritoriji severnog Ilirika u periodu od IV do početka VII veka, Arheologija i prirodne nauke 2: 47-68.

Илић, О. 2008. Палеохришћански литургијски предмети и делови црквене опреме на територији јужне Србије, у Ниш и Византија VI, ур. М. Ракоција, 125-136. Ниш: Град Ниш, Универзитет у Нишу, Нишки културни центар.

Јанковић, Ђ. 1983. Рановизантијски Гамзиград, у Гамзиград - касноантички изарски двораи, ур. С. Ђелић, 120-141. Београд: Српска академија наука и уметности.

Khrushkova, L. 2018. Unpublished and Little-Known Late Antique and Byzantine Artifacts from the Eastern Black Sea Region, Archaeologia Bulgarica XXII/2: 61-102.

Любенова, В. 1995. Бронзови предмети от късноантичната вила при рудник „Бела вода“, Перник, Археология 3/1995: 6-17.

Lovag, Zs. 1999. Mittelalterliche Bronzegegenstände des Ungarischen Nationalmuseums. Budapest: Magyar Nemzeti Muzeum.

Migne, J. Р. прир. 1865. Traditio Catholica. Saeculum VIII-IV, Annus 715-806. Tov عv

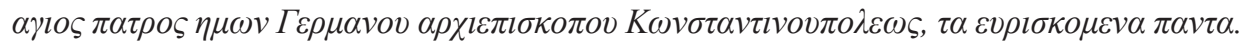
S. P. N. Germani Archiepiscopi Constantinopolitani, Opera Omnia, Juxta editiones card. Ang. Mai, Joan. Dominici Mansi, Jacobi Gretseri, Francisci Combefissi ad prelum revocata. Accedunt... Scripta quae supersunt. Tomus Unicus. Paris: Lutetiae Parisiorum.

Милинковић, М. 2015. Рановизантијска насеља у Србији. Београд: Досије студио.

Микић-Антонић, Б. 2003. Археолошки одсек, у Градски музеј Бечеј 1953-2003, ур. Б. Микић-Антонић, 36-77. Бечеј: Градски музеј Бечеј.

Minić, D. и Vukadin, O. 2007. Srednjovekovni Stalać. Beograd: Arheološki institut.

Миловановић, Д. 2008. Ризнице манастира Хиландар. Београд: Музеј примењене уметности.

Мирковић, Л. 1918. Православна литургика или наука о богослужењу православне Источне иркве - Први, опћи део, Сремски Карловци: Српска манастирска штампарија.

Sales-Carbonell, J, Sancho Planas, M, De Castellet, L. 2017. 'Incensium in monasterium' in Preandalusian Hispania (centuries $5^{\text {th }}-8^{\text {th }}$ ), Hortus Atrium Mediaevalium 23/1: 107-113.

Sandin, K. 1993. Liturgy, Pilgrimage, and Devotion in Byzantine Objects, Bulletin of the Detroit Institute of Arts 67: 46-56.

Szekeres, L. 1983. Középkori települések Északkelet-Bácskában, Novi Sad: Forum Könyvkiadó, A Magyar Nyelv, Irodalom és Hungarológiai Kutatások.

Станојев, Н. 1996. Средюовековна насеља у Војводини, Нови Сад: Музеј Војводине. Стевановић, М., Марковић, С., Матић, С., Пешикан, М. прир. 1967. Речник срnскохрватскога књижевног језика 2, Ж-К. Нови Сад - Загреб: Матица српска, Матица хрватска.

Touchais, G. et al. 1998. Chronique des fouilles et découvertes archaéologiques en Grèce en 1996 et 1997, Bulletin de correspondence hellénique 122: 705-988. 
Ћоровић-Љубинковић, М. 1950. Стара кадионица из околине Куршумлије, Музеји 5: 70-86.

Frazer, М. Е. и Evans, Н. С. 1999. Censer, with Six Figures, y Mirror of the Medieval World, yp. W. D. Wixom, 37. New York: The Metropolitan Museum of Art.

Фундулис, J. 2004. Литургика I - Увод у свето богослужење. Краљево: Епархијски управни одбор Епархије жичке.

Шпехар, П. 2017. Централни Балкан од 7. до 11. века-Археолочка сведочанства. Београд: IP Booka. 


\section{Raško Ramadanski}

Town Musem Bečej

\section{Aleksandar Ristić}

National Library "Dr Milovan Spasić" Rekovac

Faculty of Philosophy, University of Belgrade

\section{A CENSER FROM THE SITE OF PERLEK-HUMKA NEAR BEČEJ}

Keywords: Perlek, Bečej, Bačka, early Byzantine period, censer, liturgical item

The censer from the site of Perlek - Humka near Bečej in Bačka, despite being a stray find, can be considered a rather significant discovery. Censers, in general, are scarce finds and the specimen from Perlek, given its characteristics, represents a unique find in the archaeological landscape of modern Serbia and the region. It is plausible that this censer is from the $6^{\text {th }}$ or the first half of the $7^{\text {th }}$ century, thus being identified as an early Byzantine item. Bringing the censer into connection with a particular workshop is not a simple task. Suggested by what parallels from South-eastern Europe, Asia Minor and the Black Sea area we can gather, the location of the workshop that made the censer was likely somewhere in the Eastern Mediterranean. Even though this find is lacking a documented archaeological context, the origin of this item in a territory that wasn't associated with the Byzantine Empire at all can only be a matter of assumption. One of the more probable possibilities is that it was brought as loot from one of the raids carried out by Avars or Slavs in the Prefecture of Illyricum. The find of the censer from the site of Perlek - Humka represents one of the earliest examples of Christian material culture in the Bačka region. 